\title{
State based factors affecting inward FDI employment in the U.S. Economy
}

\author{
Lucyna Kornecki, $\mathrm{PhD}^{\mathrm{a} *}$, E. M. Ekanayake ${ }^{\mathrm{b}}$ \\ ${ }^{a}$ Embry-Riddle Aeronautical University, Florida, USA
}

\begin{abstract}
This empirical research investigates state based factors affecting the inward FDI employment among fifty states of the United States, uses annual data for the period of time from 1997 to 2007 and identifies several state-specific determinants of FDI employment. The results indicate that the major factors exerting positive impact on inward US FDI employment are: real wages, infrastructure, unionization level, educational attainment, FDI stock and manufacturing density. In addition, the results show that gross state product growth rate, real per capita taxes and share of scientists and engineers have negative impact on FDI employment. Our findings indicate the importance of selected variables in evaluating the effects of FDI flow
\end{abstract}

Keywords: FDI, Growth, Employment, State, Economy

\section{(C) 2012 Published by SSBF.}

\section{Introduction}

Foreign direct investment (FDI) plays an extraordinary and growing role in the global business and represents an integral part of the U.S. economy. The inward FDI constitutes important factor contributing to output growth and employment in the U.S. economy. The United States continues to be the leading destination for foreign direct investment (FDI) and the leading investor in other economies. Kearney's index ranks World inward FDI and reveals FDI flows and the factors that drive corporate decisions to invest abroad. The major finding in A.T. Kearney's 2010 FDI report indicates that China and United States are the most attractive FDI locations in the world and have achieved unprecedented levels of investor confidence. The United States remains a strong FDI magnet in the World economy. Recently, China, India, and Brazil made the top spots of Kearney's FDI Confidence Index (http://www.atkearney.com/gbpc/foreign-direct-investment-confidence-index).

Foreign companies and their U.S. subsidiaries generate enormous economic benefits for the American economy and bring billions of investment dollars into the United States, create thousands of in- sourced American jobs, and highlight the importance of the U.S. market for foreign companies. The state development agencies have an established framework of financial incentives to influence the final business location decision. Typical state inducements may include: low-interest loans, reduced income, sales, or property tax liability and grants for training or infrastructure improvement (http://www.areadevelopment.com/LocationUSA/).

\footnotetext{
* Lucyna Kornecki. Tel. 386 -226-4963 fax. 386 -226-6696

E-mail address: korneckl@erau.edu
} 


\section{Literature Review and Hypotheses}

The empirical literature related to the state based determinant of FDI employment in the U.S. is limited. In evaluating the effects of FDI on the local economies, economists focus primarily on the performance of foreign-owned subsidiaries operating in the U.S. It is already known that the establishment of a new foreign subsidiary or the expansion of an already existing one leads to higher employment and wages (Axarloglou, 2005). Reserchers identified link between job growth in the U.S. economy during a period of increasing foreign direct investment flow. The economic impact on U.S. employment due to FDI is evident, as are linkages among the various benefits due to the inward flow of FDI (Craig, 2008).

Acording to Axarloglou \& Pournarakis in the last two decades, various US states offered strong economic incentives in an effort to attract FDI inflows, with the hope that FDI would stimulate local economies (Axarloglou \& Pournarakis, 2005). Axarloglou, Casey and Han analyzed the effects of FDI inflows in local economies across US states. The empirical results point out that the US economy benefits from FDI inflows in manufacturing both in terms of employment and real wages. Overall, FDI inflows have a positive and in several cases statistically significant impact on local employment and wages. However, these effects vary across US states. In some states, such as California, Michigan, Ohio and Pennsylvania, FDI inflows appear to expand both employment and wages while in others, like Florida, Georgia and Virginia appear to depress both employment and wages. Finally, in several US states, such as in Connecticut, Delaware, Kentucky, and Louisiana, FDI inflows have mixed effects on local labor markets, with predominantly negative effects on local employment and expanding effects on local wages. There is evidence that these results are due to the industry composition of FDI inflows across states. FDI inflows in Printing and Publishing, Fabricated Metals, Industrial Machinery and Transportation Equipment have positive employment and wages effects, while FDI inflows in Furniture and Leather have negative effects (Axarloglou, Casey \& Han, 2006).

The studies by Borstorff, Collum and Newton relate to FDI in the southern U.S., specifically automobile FDI in Alabama and describe state-specific features of southern states in recruiting foreign investment bringing the employment opportunities (Borstorff, Collum \& Newton, 2007). Ajaga and Nunnen a analysis complements the regression analysis of Mullen and Williams and the Markov chain approach of Bode and Nunnenkamp and presents strong evidence of favorable FDI effects on output and employment at the level of US states (Ajaga \& Nunnen, 2008). Alfaro examined the effect of foreign direct investment on growth in the primary, manufacturing, and services sectors. Foreign direct investments in the primary sector, however, tend to have a negative effect on growth, while investment in manufacturing a positive one. Evidence from the service sector is ambiguous (Alfaro, 2003). Blomstrom, Fors and Lipsey compared the relation between foreign affiliate production and parent employment in US manufacturing multinationals with that in Swedish firms. US multinationals allocated some of their more labor-intensive operations in developing countries, reducing the labor intensity in their home production. Swedish multinationals produce relatively little in developing countries and most of it in high-income countries, such as the United States and Europe associated with more employment, particularly blue-collar employment, in the parent companies (Blomstrom, Fors and Lipsey, 1997). Bode and Nunnenkamp investigated the effects of inward FDI on per-capita income and growth of the US states since the mid-1970s. This study analyzed the long-run relationships between inward FDI and economic outcomes in terms of value added and employment at the level of US states (Bode \& Nunnenkamp, 2007). The study found that employment-intensive FDI, concentrated in richer states, has been conducive to income growth, while capital-intensive FDI, concentrated in poorer states, has not.

This empirical research investigates state based factors affecting the inward FDI employment among fifty states of the United States, uses annual data for the period of time from 1997 to 2007 and identifies several state-specific determinants of FDI employment. It assumes that the major factors influencing inward US FDI employment in the US economy are: real wages, infrastructure, unionization level, educational attainment, FDI stock, manufacturing density, gross state product growth rate, real per capita taxes and share of scientists and engineers. Our findings indicate the importance of selected variables in evaluating the effects of FDI flow on state employment. 


\section{Methodology}

\subsection{Data Sources and Variables}

In order to test the implications of our models, we collected a panel of aggregate data on foreign direct investment on all U.S. states, excluding the District of Columbia. The entire data set includes 50 states for which foreign direct investment and all other relevant variables are reported over the 1997-2007 period.

In the United States, the Bureau of Economic Analysis (BEA) (http://www.bea.gov), a section of the U.S. Department of Commerce, is responsible for collecting economic data related to FDI flows. Monitoring this data is very helpful in trying to determine the impact of FDI on the overall economy, but is especially helpful in evaluating states and industry segments. The data on stock of FDI are from the U.S. Department of Commerce, Bureau of Economic Analysis (BEA) (http://www.bea.gov).

The real per capita disposable income is measured as the nominal per capita disposable income deflated by the GDP deflator in constant (2000) U.S. dollars. The real per capita taxes is measured by dividing the real state tax revenue by the state population. The nominal tax revenue for states are from various issues of the Annual Survey of State Government Finances (http://www.census.gov/govs/state/) published by the U.S. Department of Commerce. The nominal tax revenue was deflated by the GDP deflator to derive the real state tax revenue. The data on state population are from the U.S. Census Bureau (http://www.census.gov). The real per capita expenditure on education is measured by dividing the real state education expenditure by the state population. The nominal education expenditure for states are from various issues of the Annual Survey of State Government Finances (http://www.census.gov/govs/state/) published by the U.S. Department of Commerce. The nominal education expenditure was deflated by the GDP deflator to derive the real state education expenditure.

The share of scientists and engineers in the workforce, a proxy for labor quality, is collected from the National Science Foundation, Division of Science Resources Statistics, Science and Engineering Indicators 2010 (http://www.nsf.gov/statistics/seind10/). The data on FDI related employment are collected from the Bureau of Economic Analysis while the data on state employment are collected from the U.S. Department of Labor, Bureau of Labor Statistics (http://www.bls.gov). The information on real research and development expenditure is collected from the National Science Foundation, Division of Science Resources Statistics, Science and Engineering Indicators 2010 (http://www.nsf.gov/statistics/seind10/).

The data on the average wage and total state employment are collected from the U.S. Department of Labor, Bureau of Labor Statistics. Following Coughlin, Terza, and Arromdee (1991), the manufacturing density variable is measured as the manufacturing employment per square mile of state land excluding federal land. The data on manufacturing employment are collected from the U.S. Department of Labor, Bureau of Labor Statistics (http://www.bls.gov). The information on union membership is collected from http://www.unionstats.com/ maintained by Barry Hirsch (Georgia State University) and David Macpherson (Trinity University). The data on state unemployment rate are collected from the U.S. Department of Labor, Bureau of Labor Statistics (http://www.bls.gov).

\subsection{Model Specification}

Drawing on the existing empirical literature in this area, we specify the following model:

$$
\begin{aligned}
& F D I E M P=\beta_{0}+\beta_{1} E D U+\beta_{2} R F D I+\beta_{3} G D P G R+\beta_{4} P C E X P+\beta_{5} P C T A X+\beta_{6} R W A G E+ \\
& \beta_{7} U N I O N+\beta_{8} S A E+\beta_{9} M A N D E N+\beta_{10} R N D+\beta_{11} H W Y+\varepsilon
\end{aligned}
$$

Where:

FDIEMP $\quad$ FDI Related Employment 


$\begin{array}{ll}\text { EDU } & \text { Educational Attainment } \\ \text { RFDI } & \text { Real FDI Stock } \\ \text { GSPGR } & \text { Real GSP Growth Rate } \\ \text { PCEXP } & \text { Real Per Capita Exports } \\ \text { PCTAX } & \text { Real Per Capita Taxes } \\ \text { RWAGE } & \text { Real Wage } \\ \text { UNION } & \text { Union Membership (Share of Workers who are Members of Labor Unions) } \\ \text { SAE } & \text { Share of Scientists and Engineers in the Labor Force } \\ \text { MANDEN } & \text { Manufacturing Density } \\ \text { RND } & \text { Real Research and Development Expenditure } \\ \text { HWY } & \text { Highway Mileage }\end{array}$

FDIEMP $_{\text {it }}$ represents FDI related employment in state $i$ in year t; EDU $U_{i t}$ is the real per capita expenditure on education in state $\mathrm{i}$ in year $\mathrm{t}$; $\mathrm{RFDI}_{\mathrm{it}}$ represents real FDI Stock in state $\mathrm{i}$ in year $\mathrm{t}$; $\mathrm{GSPGR}_{\mathrm{it}}$ stands for real gross state product growth rate in state $\mathrm{i}$ in year $\mathrm{t}$; $\mathrm{PCEXP}_{\mathrm{it}}$ is real per capita exports in state i in year $\mathrm{t}$; PCTAX it $_{\text {symbolizes real }}$ per capita taxes in state $\mathrm{i}$ in year $\mathrm{t}$; $\mathrm{RWAGE}_{\text {it }}$ is real wage in state $\mathrm{i}$ in year $\mathrm{t}$; $\mathrm{UNION}_{\mathrm{it}}$ represents share of workers who are members of Labor Unions in state $\mathrm{i}$ in year $\mathrm{t}$; $\mathrm{SAE}_{\mathrm{it}}$ stands for share of scientists and engineers in the labor force in state $\mathrm{i}$ in year $\mathrm{t}$; $\mathrm{MANDEN}_{\mathrm{it}}$ represents manufacturing density in state $\mathrm{i}$ in year $\mathrm{t}$; $\mathrm{RND}_{\text {it }}$ relates to real research and development expenditure in state $\mathrm{i}$ in year $\mathrm{t}$; $\mathrm{HWY}_{\mathrm{it}}$ stands for highway mileage in state $\mathrm{i}$ in year $\mathrm{t}$.

Our first variable, the real per capita expenditure on education is expected to have a positive effect on foreign direct investment employment. Therefore, we would expect that $\beta_{1}>0$. Our second variable, the real FDI stock is expected to have a positive effect on FDI employment. Therefore, we would expect that $\beta_{2}>0$. Our third variable the real gross state product growth rate is expected to have positive effect on FDI employment. Therefore, we would expect that $\beta_{3}>$ 0 . The fourth variable the real per capita exports is expected to be positive. The fifth variable the real per capita state taxes usually deter FDI flows and, therefore, is expected to be negatively related to foreign direct investment employment; thus, we would expect that $\beta_{5}<0$. The sixth variable, real state per capita wages is a measure of market demand in a state and is expected to be positively related to foreign direct investment employment. Therefore, $a$ priori, we would expect that $\beta_{6}>0$. The next variable, unionization of the workforce is expected to be related positively to foreign direct investment employment. Thus we would expect that $\beta_{7}>0$.

The eight variables, the share of scientists and engineers in the workforce, a proxy for labor quality is expected to have a positive effect on foreign direct investment employment. Therefore, we would expect that $\beta_{8}>0$. The manufacturing density is expected to be related positively to foreign direct investment employment. Therefore, we would expect that $\beta_{9}>0$. As Coughlin, Terza, and Arromdee (1991) and Head, Ries and Swenson $(1995,1999)$ point out, manufacturing density could also be used as a proxy for agglomeration economies. States with higher densities of manufacturing activity is expected to attract more foreign direct investment because the foreign investors might be serving existing manufacturers. Our tenth variable, the real research and development expenditure is expected to have a positive effect on foreign direct investment employment. Therefore, we would expect that $\beta_{10}>0$. Highway mileage is a indicator of infrastructure is expected to be positively correlated with foreign direct investment employment. Therefore, we would expect that $\beta_{11}>0$.

\subsection{Empirical Results}

The results of our empirical analysis are presented in Table 3., in addition to the eleven independent variables included in Equation (1). All the variables presented in Table 3 are expressed in logarithm and the coefficient of each variable can be interpreted as elasticities. The results of the study imply that FDI employment in the U.S. is strongly influenced by the state spending on education. The coefficient of this variable is positive and statistically significant at the $1 \%$ level of significance.

The real stock of FDI has a positive and statistically significant effect on FDI related employment. The results of the study suggest that FDI employment is strongly correlated with the real FDI stock in the U.S. This could be due to the 
fact that the states with high level of FDI employment also have larger FDI stock. Real per capita exports have the positive sign and are statistically significant at the $1 \%$ level. Most of the time higher FDI stock and employment result in higher state exports.

Table 3. Determinants of FDI Related Employment in the United States, 1990-2007

Panel Least Squares Estimates, Dependent variable: FDI Related Employment

\begin{tabular}{|l|c|c|}
\hline \multicolumn{1}{|c|}{ Variable } & Coefficient & t-statistic \\
\hline Constant & $-248.2263^{* * *}$ & -13.34 \\
\hline Education & $1.6966^{* * *}$ & 9.08 \\
\hline Real FDI stock & $1.8515^{* * *}$ & 9.04 \\
\hline Real GSP Growth Rate & $-3.2924 * * *$ & -16.23 \\
\hline Real Per Capita Exports & $0.0603 * * *$ & 5.11 \\
\hline Real Per Capita Taxes & $-0.0600^{* * *}$ & -10.37 \\
\hline Real Wages & $15.5267 * * *$ & 14.13 \\
\hline Unionization & $2.5801 * * *$ & 7.79 \\
\hline Scientists and Engineers & -0.1157 & -0.68 \\
\hline Manufacturing Density & 0.0003 & 0.03 \\
\hline Real Research and Development Expenditure & 0.0000 & 0.24 \\
\hline Highway Mileage & $9.9975^{* * *}$ & 7.13 \\
\hline Adjusted R & 0.8662 & \\
\hline Number of Periods & 18 & \\
\hline Number of Cross-Sections & 50 & \\
\hline Number of Observations & 900 & \\
\hline
\end{tabular}

Note: $* * *$ indicates the statistical significant at the $1 \%$ level.

Real GSP growth rate has the unexpected negative sign and it is statistically significant at the $1 \%$ level. It can be explained by the fact, that many foreign investors choose the southern part of the U.S. as a desirable location for their FDI. The southern U.S. states has become more aggressive in recruiting foreign investment by providing incentives to attract investments and communicating the unique advantages they offer to foreign companies. The real per capita taxes has the expected negative sign and it is statistically significant at $1 \%$ level. This finding is also consistent with the findings of previous studies. Real wages have the positive sign and it is statistically significant at $1 \%$ level. It is known that foreign companies investing in U.S. not only provide jobs, but relatively high-paying jobs what constitutes important determinant of FDI employment. Unionization variable has an expected positive sign and it is statistically significant at the $1 \%$ level of significance. Surprisingly, the share of scientists and engineers in the workforce has an unexpected negative sign. It can be related to the fact that the labor force is relatively more productive and skilled in urban than in rural areas. Manufacturing density variable has the expected positive sign. This variable is also expected to capture the agglomeration economies and we can guess that the more dense the manufacturing activity is in a given state, the more likely higher foreign direct investment employment will be. However, current results reveal that the Southeast region in the U.S. stems from relatively high manufacturing density. Highway Mileage represents infrastructure level in the state and it is definitely positively correlated with the FDI employment at the $1 \%$ level of significance.

\section{Conclusion}

This paper investigates locational determinants of the inward foreign direct investment (FDI) among fifty states of the United States. In order to test the implications of our models, we collected a panel of aggregate data on foreign direct investment on all U.S. states, excluding the District of Columbia. The entire data set includes 50 states for which foreign direct investment and all other relevant variables are reported over the 1997-2007 period. US policymakers obviously expect FDI inflows to help improve income and employment prospects in the economy. 
Inward FDI represents an integral part of the U.S. economy. Most of the foreign investment in the United States comes from the European developed economies. These investments are predominately in the manufacturing sector and accounts for very high percentage of foreign direct investment in the United States. U.S. affiliates of foreign companies in the manufacturing industry is the largest contributor of FDI employment in the U.S. economy. In 2009, manufacturing employment accounted for 36.3 percent of total FDI employment in the United States. The next large industry outside the manufacturing for employment by U.S. affiliates of foreign companies was retail trade. The retail trade industry accounted for $10.9 \%$ of total FDI employment followed by wholesale $9.7 \%$ along with finance and information consecutively accounting for $6.8 \%$ and $6.4 \%$ of total FDI employment. The leading states in foreign direct investment employment are California, Texas, Ohio, Pennsylvania, Illinois, North Carolina, New York, New Jersey. The southern U.S. states have become more aggressive in recruiting foreign investment by providing incentives to attract investments.

It is known that foreign companies investing in the United States not only provide jobs, but offer relatively high-paying jobs what constitutes important factor influencing to high FDI employment and contributing to employment in the U.S. economy. Findings of our research show that real wages variable has the positive sign and it is statistically significant at $1 \%$ level. The next important factor the state highway mileage representing infrastructure is positively related to the FDI employment at the $1 \%$ level of significance. Among other findings, unionization variable, as expected is statistically significant at the $1 \%$ level of significance. It is known that the degree of unionization within U.S. affiliates of foreign companies is relatively higher in comparison with domestic companies.

The real stock of FDI has a positive and statistically significant effect on FDI related employment. This could be due to the fact that the states with high level of FDI stocks also have larger related employment. The education has the expected positive sign and it is statistically significant at $1 \%$ level. It can be concluded, that for states to attract more investment is to spend more on educations and research and development activities. The real per capita taxes has the expected negative sign and it is statistically significant at $1 \%$ level. This finding is also consistent with the findings of previous studies. Given that the current results suggest that state government taxation negatively affect foreign direct investment, state governments may consider providing more fiscal incentives to foreign investors in order to attract more foreign direct invest to their states. Real state growth rate has the unexpected negative sign and it is statistically significant at the $1 \%$ level It can be explained by the fact, that many foreign investors choose the southern part of the U.S. as a desirable location for their FDI. The southern U.S. states has become more aggressive in recruiting foreign investment by providing incentives to attract investments and communicating the unique advantages they offer to foreign companies. It could be related to the fact that that employment-intensive FDI, concentrated in richer states, has been conducive to growth, while capital-intensive FDI, concentrated in poorer states, has not. Additionally, according to Alfaro foreign direct investments in the primary sector tend to have a negative effect on growth and employment, while investments in manufacturing tend to have a positive one, while the evidence from the service sector is ambiguous (Alfaro, 2003). Surprisingly, the share of scientists and engineers in the workforce has an unexpected negative sign. It can be related to the fact that the labor force is relatively more productive and skilled in urban than in rural areas.

Our findings indicate the importance of selected variables in evaluating the effects of FDI flow on state employment. Also, they emphasize the need for U.S. to selectively target FDI in specific states and industries and make a host government's aware of importance of promotional effort to attract foreign direct investment and stimulate employment and growth at the state level contributing to overall output growth and employment in the U.S. economy. Encouraging more FDI and expanding the number of countries investing in the United States can lead potentially to higher employment and higher output growth.

\section{References}

Reference to a journal publication:

[1] Alfaro L. (2003, April) Foreign Direct Investment and Growth: Does the Sector Matter? *Harvard Business School. Available at: $<$ http://www.51lunwen.org/UploadFile/org201101310901063260/20110131090106459.pdf . 
[2] Ajaga, E. \& Nunnen, P. (2008, May) Inward FDI, Value Added and Employment in US States: A Panel Cointegration Approach* Kiel Working Paper No. 1420. Available at: www.ifw-members.ifw-kiel.de/publications/.../KWP final.pdf

[3] Axarloglou, K. (2005) What Attracts Foreign Direct Investment Inflows in the United States. The International Trade Journal 19 (3). Pages 285-308.

[4] Axarloglou, K. \& Pournarakis, M. (2005, July 20) Do All Foreign Direct Investments Benefit the Local Economy. The World Economy: Second Revision. Epanomi, Greece. Pages 1-2.

[5] Axarloglou, K., Casey, W. \& Han, H. (2006). Inward foreign direct investments in the us: an empirical analysis of their impact on state economies. Eastern Economic Journal 37(4). Pages 508-529.

[ 6] Blomstrom, M., Fors, G. \& Lipsey, R. (1997, November) Foreign Direct Investment and Employment: Home Country Experience in the United States and Sweden. The Economic Journal, Vol. 107, No. 445. Pages 1787-1797. Blackwell Publishing for the Royal Economic Society. (http://www.jstor.org).

[7] Bode, E. \& Nunnenkamp P. (2007, August) Does Foreign Direct Investment Promote Regional Development in Developed Countries? A Markov Chain Approach for US States. Kiel Working Paper No. 1374.

[ 8] Borstorff, P. C., Collum, T. H., \& Newton, S. (2007) FDI in the Southern U.S: a Case Study of the Alabama and the Automotive Sector Allied Academies International Conference. Proceedings of the International Academy for Case Studies, Volume 14, Number 1 Jacksonville.

[9] Coughlin, C. C., Terza, J. V. \& Arromdee, V. (1991) State characteristics and the location of foreign direct investment within the United States, Review of Economics and Statistics. Pages 68, 67-83.

[10] Head, C. K., Ries, J. C. \& Swenson, D. L. (1995). Agglomeration Benefits and Location Choice: Evidence from Japanese Manufacturing Investments in the United States. Journal of International Economics (38). Pages 223-247.

[11] Head, C. K., Ries, J.C. \& Swenson, D.L. (1999), "Attracting Foreign Manufacturing: Investment Promotion and Agglomeration", Regional Science and Urban Economics, Vol. 29. Pages 197-218

Reference to a web source:

[12] Kearney's FDI Confidence Index (http://www.atkearney.com/gbpc/foreign-direct-investment-confidence-index).

[13] (http://www.areadevelopment.com/LocationUSA/).

[14] National Science Foundation, Division of Science Resources Statistics, Science and Engineering Indicators (http://www.nsf.gov/statistics/seind10/).

[15] The U.S. Department of Commerce. Annual Survey of State Government Finances (http://www.census.gov/govs/state/).

[16] The U.S. Department of Commerce, Bureau of Economic Analysis (BEA) (http://www.bea.gov).

[17] The U.S. Department of Labor, Bureau of Labor Statistics (http://www.bls.gov).

[18] The U.S. Census Bureau (http://www.census.gov).

[19] Union Membership and Coverage Database from the CPS (http://www.unionstats.com). 